\title{
Localization of intracellular proteins at acetylcholine receptor clusters induced by electric fields in Xenopus muscle cells
}

\author{
M. WILLIAM ROCHLIN and H. BENJAMIN PENG* \\ Department of Cell Biology and Anatomy, Laboratories for Cell Biology, \& the Neurobiology Cumiculum, University of North Carolina, Chapel \\ Hill, NC 27599, USA \\ - Author for correspondence at: Department of Cell Brology and Anatomy, University of North Carolina, CB\#7090, 108 Swing Bldg, Chapel \\ Hill, NC 27599-7090, USA
}

\begin{abstract}
Summary
Electric fields cause acetylcholine receptor (AChR) patches to form on the cathodal sides of cultured muscle cells. These patches are stable for several hours following cessation of an electric field treatment, indicating that the receptors are anchored to the cluster sites. Furthermore, at the ultrastructural level, AChR patches induced by electric fields are marked by an accumulation of extracellular matrix material and a sarcolemmal density. Thus, these $A C h R$ patches are similar to those induced by other stimuli, including nerve, polycation-coated beads, and the tissue culture substratum. Proteins that may be involved in anchoring $\mathrm{AChRs}$ have been colocalized with AChR patches induced by the latter three stimuli, but not at AChR patches induced by electric fields. In this study, we demonstrate that three putative anchoring proteins, $43 \mathrm{~K}$
\end{abstract}

$\left(\mathrm{K}=10^{3} M_{\mathrm{r}}\right)$ protein, $58 \mathrm{~K}$ protein and talin, are associated with field-induced AChR patches. We also show that these proteins persist at fieldinduced AChR patches following removal of the field, indicating that they are stabilized at the AChR patch. Our data are consistent with the possibility that these proteins contribute to the stabilization of AChRs at patches induced by the electric field. Since $43 \mathrm{~K}, 58 \mathrm{~K}$ and talin are intracellular proteins, and therefore could not undergo field-induced lateral electrophoresis, our observations support the notion that the electric field triggers the formation of an AChR-stabilizing specialization.

Key words: electric field, acetylcholine receptor, $43 \mathrm{~K}$ protein, $58 \mathrm{~K}$ protein, talin.

\section{Introduction}

The clustering of acetylcholine receptors (AChRs) at nicotinic synapses is essential for proper signal transmission. A variety of stimuli are capable of inducing AChR patch formation in cultured muscle cells, including nerve (Anderson \& Cohen, 1977), polycation-coated beads (Peng, 1987), the substratum (Bloch \& Geiger, 1980; Moody-Corbett \& Cohen, 1982a), soluble factors (Godfrey et al. 1984; Christian et al. 1978; Usdin \& Fischbach, 1986), and electric fields (Orida \& Poo, 1978). Ultrastructurally, the AChR patches induced by nerve (Peng et al. 1979; Takahashi et al. 1987), bead (Peng \& Phelan, 1984), substratum (Weldon et al. 1981; Peng, 1987) and electric field (Luther \& Peng, 1985) in tissue culture are similar to the nascent $\mathrm{AChR}$ plaques that form at the neuromuscular junction (NMJ) in vivo (Kullberg et al. 1977). A variety of antigens have been colocalized with $\mathrm{AChR}$ patches induced by nerve, bead and substratum, and may be involved in anchoring AChRs at these sites (Bloch \& Pumplin, 1988). Colocalization of these antigens with electric field-induced $A C h R$ patches has not been studied. Unlike the other stimuli, an electric field induces AChR clustering without physical or chemical contact being made with the muscle cells. Such a difference may be important in determining whether putative anchoring proteins are associated with the fieldinduced AChR patches. Indeed, we recently reported that the colocalization of one protein (talin, see below) with AChR patches depended on the stimulus used to induce the post-synaptic specialization (Rochlin et al. 1989a). Thus, it is of interest to document the colocalization of field-induced receptor patches (FIRPs) and molecules that are concentrated at NMJs. To this end, we have examined the distribution of three proteins, $43 \mathrm{~K}$ $\left(\mathrm{K}=10^{3} M_{\mathrm{r}}\right)$ protein, talin and $58 \mathrm{~K}$ protein, in electricfield-treated muscle cells.

The $43 \mathrm{~K}$ protein is a peripheral membrane protein that was first isolated from the nicotinic synapse-rich postsynapse membrane of Torpedo electric organ (Sobel et al. 1977). It probably binds directly to the AChR (Burden et al. 1983), although the subunit to which it binds has not 
been unambiguously determined (Krikorian \& Bloch, 1989). Conditions that disrupt the AChR-43K association, such as alkaline $\mathrm{pH}$, increase the rotational and diffusional coefficients of AChRs in isolated postsynaptic membrane fragments from Torpedo (Lo et al. 1980). Antibody cross-linking the $43 \mathrm{~K}$ protein or the $\mathrm{AChR}$ in isolated membranes results in co-microclustering of both proteins (Bloch et al. 1989). Thus, the $43 \mathrm{~K}$ protein is generally believed to have an intimate role in AChR clustering, regardless of the stimulus (however, see Discussion).

In contrast to $43 \mathrm{~K}$ protein, talin and $58 \mathrm{~K}$ protein are elevated not only at AChR patches, but also at sites that do not have receptor patches, such as myotendinous junctions (Tidball et al. 1986; Chen et al. 1989). Talin is a $235 \mathrm{~K}$ protein that is involved in the linkage between the cytoskeleton and the extracellular matrix. It is concentrated at focal adhesions, and binds to integrins and vinculin in vitro (Burridge et al. 1988). We and others have shown that talin is present at some NMJs in vivo and at $A C h R$ patches that form on cultured muscle cells (Rochlin et al. 1989a; Sealock et al. 1986). Talin is more likely to be elevated at AChR patches that form in association with a substratum, such as that of the coverslip or polycation-coated beads, than with nerveinduced AChR patches. In addition, the distribution of talin at talin-positive AChR patches is frequently different from that of AChRs (Rochlin et al. 1989a). The correlation between talin accumulation and AChR patches is not $1: 1$, so clarifying its association with FIRPs will contribute to our understanding of its role in post-synaptic specialization formation.

The $58 \mathrm{~K}$ protein has an association with $\mathrm{AChR}$ patches that is intermediate between that of the $43 \mathrm{~K}$ protein and talin. Like the $43 \mathrm{~K}$ protein, the $58 \mathrm{~K}$ protein is a peripheral membrane protein originally isolated from Torpedo electric organ (Froehner, 1984). The $58 \mathrm{~K}$ and $43 \mathrm{~K}$ proteins are codistributed with $\mathrm{AChR}$-rich domains of spontaneously formed AChR patches (hotspots) in vitro (Froehner et al. 1987). However, $58 \mathrm{~K}$ protein is elevated at the myotendinous junction in the same pattern as talin, and both $58 \mathrm{~K}$ and talin are elevated at sites of myofibril-membrane interaction in muscle cells in culture independent of AChR clusters (Chen et al. 1989). Thus, the proteins we have selected represent three different classes of AChR patch association, and will help us define the similarity of the electric fieldinduced AChR patches to those induced by other stimuli. (This work was previously communicated in abstract form; Rochlin et al. (1989b).)

\section{Materials and methods}

\section{Culture preparation}

Cultures were prepared from Xenopus laevis embryos between stages 15 and 19 (Nieuwkoop \& Faber, 1967) essentially as described before (Peng \& Nakajima, 1978). Briefly, this entails separating the dorsal portion of the embryo (which contains myotomal and neural tissue) from the ventral portion of the embryo and dissociating the cells in a calcium-free, magnesiumfree solution (CMF). However, prior to CMF treatment the dorsal portions of the embryos were placed in collagenase $\left(1 \mathrm{mg} \mathrm{ml}^{-1}\right)$ for $30 \mathrm{~min}$, and the skin and neural tissue were dissected away.

\section{Field application}

The chamber used to apply the field has already been described (Luther \& Peng, 1985). The dimensions of the chamber are $18 \mathrm{~mm} \times 5 \mathrm{~mm} \times 0.35 \mathrm{~mm}$. Field strengths of $4 \mathrm{~V} \mathrm{~cm}^{-1}$ or $7 \cdot 5 \mathrm{~V} \mathrm{~cm}^{-1}$ were delivered by a constant-voltage power supply (IBI CPS 500). Current was continuously monitored from a Keithley 173A digital multimeter. The voltage difference across the chamber was measured. Current densities of 27 or $49 \mathrm{~mA} \mathrm{~cm}^{-2}$ were used. The resistivity of the culture medium is $160 \mathrm{ohm} \mathrm{cm}$. Chamber voltage was checked twice during 1-h field treatments and three times during 3-h field treatments, and minor adjustments to the current were made when necessary.

\section{Experimental treatments}

Cultures of 1-day-old cells were treated with a $4 \mathrm{~V} \mathrm{~cm}^{-1}$ field for $1 \mathrm{~h}$, followed by a 2 -h post-field recovery (PFR). During the last half hour of PFR, the coverslips were incubated in culture medium containing $300 \mathrm{nM}$-tetramethylrhodamine-conjugated $\alpha$-bungarotoxin (R-BTX). Cultures of 1-or 2-day-old cells were treated with a $7.5 \mathrm{~V} \mathrm{~cm}^{-1}$ field for $3 \mathrm{~h}$. These cultures were labelled with $300 \mathrm{~nm}-\mathrm{R}-\mathrm{BTX}$ proor to field treatment and $10 \mathrm{~nm}$ $\mathrm{R}-\mathrm{BTX}$ during field treatment. The 1-day-old cells treated with the $7.5 \mathrm{~V} \mathrm{~cm}^{-1}$ field were placed on ice immediately after field treatment until fixation. The 2-day-old cells were permitted a brief (less than $15 \mathrm{~min}$ ) PFR prior to fixation. The experiments in which 1-day-old and 2-day-old cultures were compared were performed on different sets of cultures than experiments in which 1-day-old cultures were compared for the different fieldtreatment protocols. Therefore, data for the two sets of experiments were treated separately and are presented separately. Cultures were fixed by submersion in $95 \% \mathrm{EtOH}$ for $3.75 \mathrm{~min}$ at $-20^{\circ} \mathrm{C}$. Following three rinses in PBS, coverslips were incubated in blocking buffer (containing $20 \mathrm{~mm}$ Tris- $\mathrm{HCl}, 0.1 \% \mathrm{BSA}, 5 \%$ normal goat serum, and $0.1 \%$ fish gelatin) for $0.5-1 \mathrm{~h}$ at room temperature. Next, coverslips were treated with either rabbit anti-talin serum (Burndge \& Connell, 1983), mouse anti-58K IgG (mab1351; Froehner et al. 1987) or mouse anti-43K IgG (mab1234; Peng \& Froehner, 1985) dissolved in blocking buffer overnight at $4^{\circ} \mathrm{C}$. Some control coverslips were maintained in the blocking buffer and not treated with primary antisera. Following three 10 -min washes in blocking buffer without normal goat serum or fish gelatin, the coverslips were stained with the appropriate (anti-rabbit or antimouse) FITC-conjugated secondary antibody for $4-6 \mathrm{~h}$ at $4^{\circ} \mathrm{C}$. Coverslips were then washed three times for $10 \mathrm{~min}$ as above, rinsed once in PBS, and mounted in a polyvinyl alcohol-based resin.

Some 1-day-old cells were stained with R-BTX prior to live observation. In these instances, cells were selected for observation if they were free of spontaneous receptor patches on the side that would face the cathode.

\section{Evaluation of colocalization of antigens and receptor clusters}

Two protocols were used to assess different aspects of colocalization of antigens with receptor clusters. The first was experimenter-based: cells were examined under rhodamine and then FITC optics and if antigen staining was elevated at the cathodal cluster site, then the antigen was considered to be colocalized with the cathodal receptor patch. This method provided a subjective analysis of elevation of antigens at FIRPs with respect to the immediately surrounding volume of the cathode- 
facing side of the cell. The human eye is better suited to this border detection than to comparing brightness differences between two well-separated areas. Therefore, we used digital imaging techniques to determine if the antigen staining at FIRPs was brighter than that at a corresponding region of the anode-facing side of the cell, as described below.

The second protocol was computer-based: rhodamine and fluorescein images of the same cells were digitized and recorded on an IBM AT computer using a SIT camera. The fluorescence of the toxin at a cathodal cluster was assessed by generating an outline of the receptor patch with boundary-sensing software, and determining the average pixel value of the outlined area. The outline of a comparable region on the anodal side of the cell was obtained manually, and the average pixel value of this region determined. Next, the fluorescein image, representing the antigen staining, was viewed and positioned so as to correct for the shift caused by changing the filter set. The same outlines used to average the pixel values of the rhodamine image were used to average the identical regions in the fluorescein image. Although the field induced several cathodal clusters per cell, only one cluster/cell was assessed by this method. Brighter FIRPs were selected, since we assumed that the antigen's signal-to-noise ratio would be higher and therefore mitigate the influence of the higher background associated with antibody (versus R-BTX) staining. As is evidenced in Figures 4-6 (below), this elevation is usually detectable at all FIRPs on a cell. Imaging software purchased from G. W. Hannaway \& Associates (Boulder, $\mathrm{CO}$ ) was employed in this analysis.

An asymmetry index (AI) was used to assess whether the cathodal region was brighter than the anodal region of these cells. $\mathrm{AI}=(\mathrm{CCPV}-\mathrm{APV}) /(\mathrm{CCPV}+\mathrm{APV})$, where $\mathrm{CCPV}$ is the average cathodal cluster pixel value for a given cell and APV is the average anodal pixel value for the same cell. Thus, if the $A P V$ was zero, then $A I=1$, and if the $A P V=C C P V$, the $A I=0$. To determine if the $A I$ was significantly different from zero, values of $\mathrm{CCPV} /(\mathrm{CCPV}+\mathrm{APV})$ and $\mathrm{APV} /(\mathrm{CCPV}+$ APV) from each cell were compared using a paired $t$-test. Background was defined as the lowest pixel value in the optical field (usually $5-10 \%$ of the APV) and subtracted prior to calculation of the AI.

It should be noted that cathodal AChR patches that were located on the ends of the cells were not used in assessing colocalization of talin or $58 \mathrm{~K}$ protein, since these antigens were elevated at the ends of all cells regardless of field treatment or the presence of $\mathrm{AChR}$ clusters. Pieces of yolk often were attached to the edges of cells and sometimes were associated with AChR patches. These receptor patches were excluded from analysis. In general, FIRPs that were used in colocalization analysis were located along the edge of the muscle cells, not in association with the cell substratum. In most cases, fieldtreated cells exhibited FIRPs in multiple dorsal-ventral planes along the cathodal edge. Frequently, muscle cells emitted small lamellipodia towards the cathode, as has been reported for nonmuscle cells in these cultures (Luther et al. 1983). Although these lamellipodia were often the sites of receptor patches, they were not used for asymmetry measurements because correspondingly thin region of an anode-facing edge could not be found.

\section{Results}

\section{Untreated cultures and live observations}

To control for the possibility that the cathodal AChR clusters are hotspots, not induced by the field, the percentage of cells with hotspots on an edge was evaluated. This percentage was divided in half, since only half

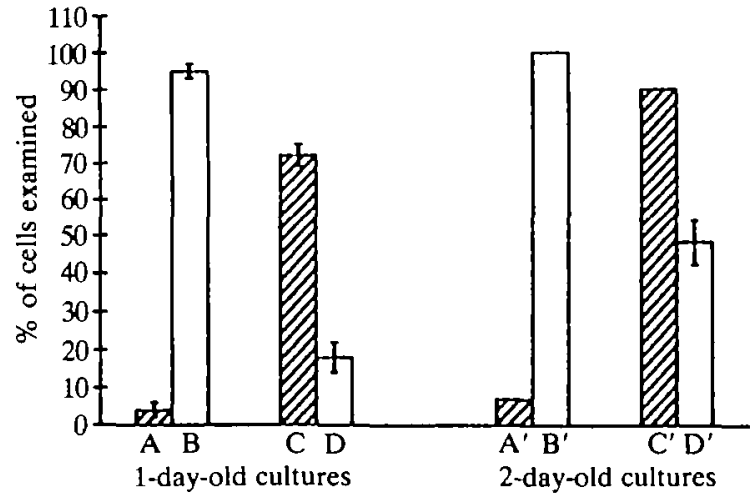

Fig. 1. Control for pre-existing AChR clusters on the cathode-facing edge of the muscle cell, and an evaluation of field-induced hotspot reduction. A, $\mathrm{A}^{\prime}$. The percentage of untreated cells with hotspots on an edge was recorded. Only those edge hotspots that resembled FIRPs were counted (see Materials and methods). The unweighted average ( \pm S.E.M.) of the percentages obtained from different experiments was determined, and then halved to account for those that would have faced the cathode. $\mathrm{B}, \mathrm{B}^{\prime}$. The percentage of $4 \mathrm{~V} \mathrm{~cm}^{-1}$ field-treated 1-day-old cells with cathodal clusters. C.C'. The percentage of untreated cells that had hotspots. D.D'. The percentage of $7.5 \mathrm{~V} \mathrm{~cm}^{-1}$ field-treated 2-day-old cells that had hotspots. On field-treated cells, AChR staining away from the cathode-facing edge constituted hotspots. Data base (no. expts, no. cells): A,C, $(3,162) ; \mathrm{B},(9,578) ; \mathrm{D},(4,279)$; $\mathrm{A}^{\prime}, \mathrm{C}^{\prime},(2,90) ; \mathrm{B}^{\prime},(3,121) ; \mathrm{D}^{\prime},(3,109)$.

of the hotspots would have been on the cathode-facing side of the cell. Hotspots on the ends of the cells were not included, and small $\left(<0.5 \mu \mathrm{m}^{2}\right)$ hotspots that would not have been mistaken for field-induced AChR patches were not included in the analysis. Field treatments were carried out on 1- and 2-day-old cultures, so the hotspot analysis was carried out on 1 - and 2 -day-old cells. Less than $4 \%$ of the 1 -day-old cells, and less than $7 \%$ of the 2 day-old cells had hotspots associated with a designated edge (Fig. 1A and $A^{\prime}$ ). In contrast, over $95 \%$ of 1 -dayold cells treated with the $4 \mathrm{~V} \mathrm{~cm}^{-1}$ protocol and 2-day-old cells treated with the $7.5 \mathrm{~V} \mathrm{~cm}^{-1}$ protocol had cathodal AChR patches (Fig. $1 B$ and $B^{\prime}$ ).

As an additional control, we also monitored some living, R-BTX-labelled cells during field treatment. Of six 1-day-old cells that did not have cathodal patches prior to field application all did have detectable cathodal patches within $40 \mathrm{~min}$ of field application (Fig. 2, arrowheads). Thus, the electric field induces $A C h R$ patch formation on cathode-facing cell edges, and hotspots are unlikely to be mistaken for FIRPs.

\section{Hotspot reduction in field-treated cells}

We also examined the efficacy of the electric field in decreasing the number of cells with hotspots. One-dayold cells treated with a $4 \mathrm{~V} \mathrm{~cm}^{-1}$ field for $1 \mathrm{~h}$ and a $2 \mathrm{~h}$ PFR were four times less likely to have hotspots than untreated cells (Fig. 1; untreated, C; treated, D). Twoday-old cultures treated with a $7 \cdot 5 \mathrm{~V} \mathrm{~cm}^{-1}$ field for $3 \mathrm{~h}$ and a $15-\mathrm{min}$ PFR were two times less likely to have hotspots than untreated cultures (Fig. 1; untreated, $\mathrm{C}^{\prime}$; treated, $\left.\mathrm{D}^{\prime}\right)$. Thus, the electric field, like nerve and 

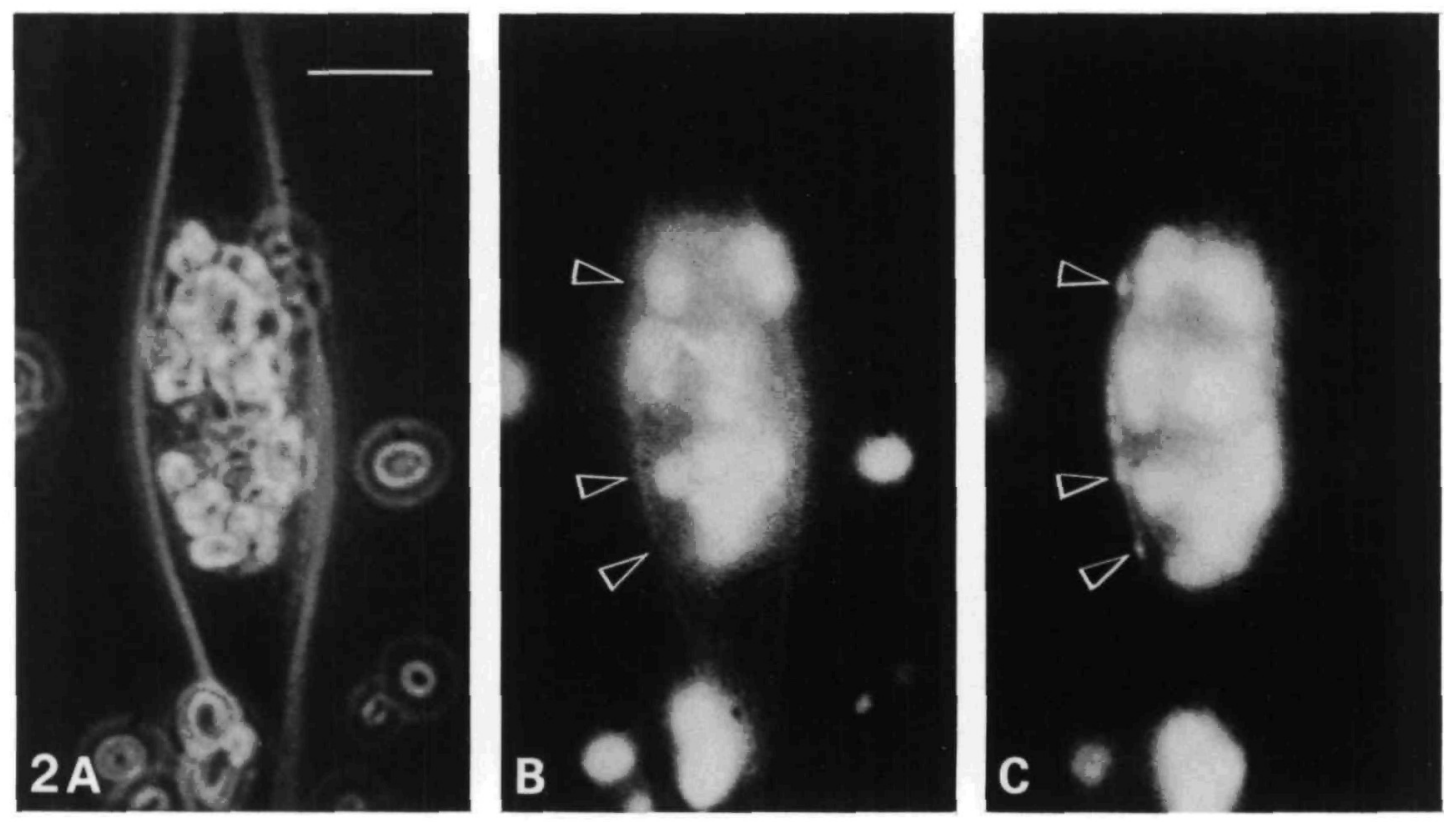

Fig. 2. FIRP formation on a formerly hotspot-free cathodal edge. A. Digitized phase-contrast image showing absence of debris from cathodal (left) edge. B. Hotspot-free cathodal edge prior to field treatment. C. FIRPs on same edge during $4 \mathrm{~V} \mathrm{~cm}^{-1}$ field application, $25 \mathrm{~min}$ after onset. Note that the AChR staining is elevated in patches, rather than uniformly along the cathode facing edge of the cell (arrowheads). The bright staining of spherical structures in the middle of the cell and outside the cell is due to the autofluorescence of yolk platelets. Bar, $10 \mu \mathrm{m}$.

polycation-coated beads, reduces hotspot formation and survival.

\section{Control cultures}

To determine whether non-specific secondary antibody staining influenced the asymmetry index (AI, see Materials and methods), AI values were obtained from fieldtreated cultures that were stained only with R-BTX (Fig. 3A) and one of the secondary antibodies (FITClabelled donkey anti-rabbit in Fig. 3B, or FITC-labelled goat anti-mouse). The AI for the AChR staining was approximately 0.475 , and significantly different from zero $(P<0.001$, paired $t$-test) (Table 1$)$. In both cases, the AI values for the FITC image were small $( \pm 0.02)$ and not significantly different from zero $(P<0.28$ for

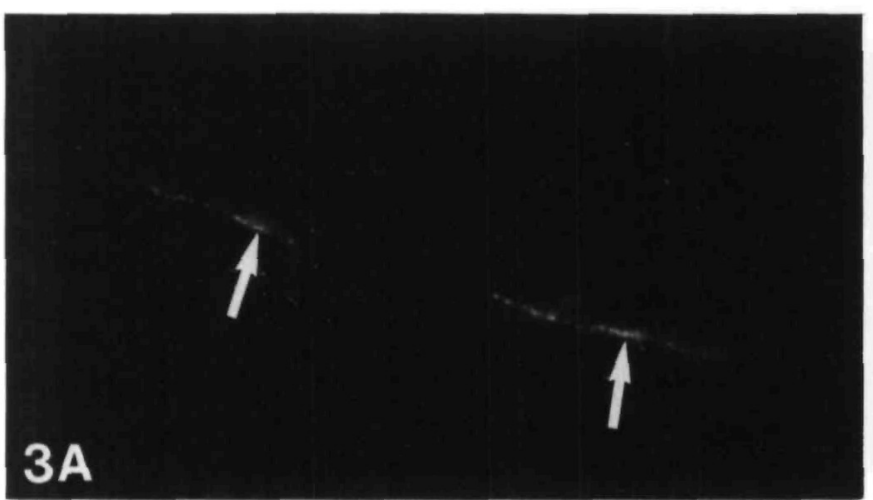

both secondary antibodies). Thus, non-specific staining was minimal.

\section{Field-propelled translocation or field-triggered anchor formation}

There are two mechanisms that might be effecting the asymmetry in the distribution of AChRs, electric fieldpropelled AChR translocation and electric field-triggered AChR-anchor formation. If electric field-propelled AChR translocation is primarily responsible for generating the asymmetry, then the asymmetry should be greatest after a longer-duration, high field strength treatment and no PFR. If the electric field is triggering the AChR-anchor formation, then the asymmetry should be

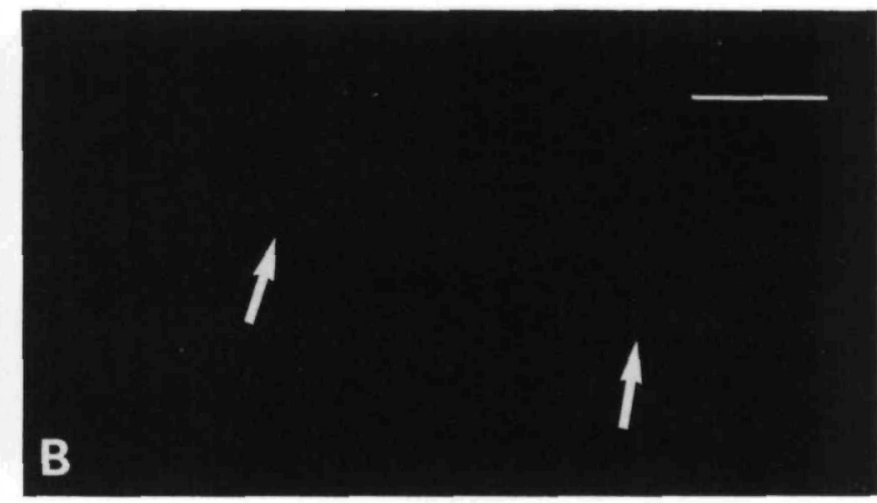

Fig. 3. Control for primary antibody staining at FIRPs. In this example, 1-day-old cells were treated with the 1-h field, 2-h PFR protocol (see text). A. R-BTX staining showing the FIRP. B. Fluorescein optics showing donkey anti-rabbit staining following an exposure suitable for rabbit anti-talin staining. Very little nonspecific staining is evident in B. Cathode is towards the bottom in this micrograph. Bar, $10 \mu \mathrm{m}$. 
Table 1. Controls for primary antibody staining at Field-induced AChR clusters

A. Computer-based quantitation

\begin{tabular}{|c|c|c|c|c|}
\hline Treatment & $\begin{array}{c}\text { Age } \\
\text { (days) }\end{array}$ & $\begin{array}{l}\text { AChR AI* } \\
\text { 土s.E.M. }\end{array}$ & $\begin{array}{l}\text { Secondary } \\
\text { antibody AI } \\
\text { 土s.E.M. }\end{array}$ & No. expts, no. cells \\
\hline $\begin{array}{l}\text { 1-h } 4 \mathrm{~V} \mathrm{~cm}^{-1}, 2 \text {-h PFR, } \\
\text { anti-rabbit control }\end{array}$ & 1 & $0 \cdot 463 \pm 0.053$ & $0 \cdot 013 \pm 0 \cdot 015$ & 2,10 \\
\hline $\begin{array}{l}\text { 1-h } 4 \mathrm{~V} \mathrm{~cm}^{-1}, 2 \text {-h PFR, } \\
\text { anti-mouse control }\end{array}$ & 1 & $0 \cdot 497 \pm 0 \cdot 028$ & $0.020 \pm 0 \cdot 017$ & 2,10 \\
\hline \multicolumn{5}{|c|}{ B. Experimenter-based quantitation } \\
\hline Treatment & $\begin{array}{c}\text { Age } \\
\text { (days) }\end{array}$ & $\begin{array}{l}\text { \%o cells with } \\
\text { FIRPs }\end{array}$ & $\begin{array}{l}\text { \% FIRPs with } \\
\text { 2nd antıbody }\end{array}$ & No. expts, no. cells \\
\hline $\begin{array}{l}\text { 1-h } 4 \mathrm{~V} \mathrm{~cm}^{-1}, 2 \text {-h PFR } \\
\text { anti-rabbit control }\end{array}$ & 1 & 100 & 0 & 2,10 \\
\hline $\begin{array}{l}\text { 1-h } 4 \mathrm{~V} \mathrm{~cm}^{-1}, 2 \text {-h PFR } \\
\text { antı-mouse control }\end{array}$ & 1 & 100 & 0 & 2,10 \\
\hline
\end{tabular}

independent of field strength and PFR. We compared the mean AI of 1-day-old muscle cells treated with a $1-h$ $4 \mathrm{~V} \mathrm{~cm}^{-1}$ field and 2-h PFR with the mean AI of 3-h $7.5 \mathrm{~V} \mathrm{~cm}^{-1}$ field without a PFR. The difference between the AI values for each treatment is less than $7 \%$ of the smaller AI and is not significant $(P>0.02, t$-test $)$. Thus, the AI of AChRs is not strongly influenced by field strength, duration of application, and PFR (Table 2) under these conditions.

$43 \mathrm{~K}$ protein in untreated and field-treated muscle cells The $43 \mathrm{~K}$ protein (Fig. 4B) was always present at hotspots (Fig. 4A) on field-treated and untreated cultures (Fig. 4C). As expected, staining for the $43 \mathrm{~K}$ protein (Fig. 4E,H) was identical to that of the FIRP (Fig. 4D,G). Note that each of the small patches are precisely colocalized with the $43 \mathrm{~K}$ protein (arrows in Fig. 4D-I). Furthermore, all FIRPs were sites of elevated $43 \mathrm{~K}$ (Table 3 ) and $43 \mathrm{~K}$ was only elevated at sites of
Table 2. AChR asymmetry at field-induced $A C h R$ clusters

\begin{tabular}{|c|c|c|c|}
\hline Treatment & $\begin{array}{l}\text { Age } \\
\text { (days) }\end{array}$ & $\begin{array}{l}\text { AChR AI* } \\
\text { 土s.E.M. }\end{array}$ & $\begin{array}{l}\text { No. expts, } \\
\text { no. cells }\end{array}$ \\
\hline $\begin{array}{l}\text { 1-h } 4 \mathrm{~V} \mathrm{~cm}^{-1}, 2-\mathrm{h} \text { PFR } \\
3-\mathrm{h} 7.5 \mathrm{~V} \mathrm{~cm}^{-1} \text {, no PFR }\end{array}$ & $\begin{array}{l}1 \\
1\end{array}$ & $\begin{array}{l}0.516 \pm 0.011 \\
0.550 \pm 0.012\end{array}$ & $\begin{array}{l}2,72 \\
2,78\end{array}$ \\
\hline $\begin{array}{l}\text { 1-h } 4 \mathrm{~V} \mathrm{~cm}^{-1}, 2-\mathrm{h} \text { PFR } \\
3-\mathrm{h} 7.5 \mathrm{~V} \mathrm{~cm}^{-1}, 0 \cdot 2-\mathrm{h} \text { PFR }\end{array}$ & $\begin{array}{l}1 \\
2\end{array}$ & $\begin{array}{l}0.434 \pm 0.012 \\
0.443 \pm 0.017\end{array}$ & $\begin{array}{l}3,87 \\
3,68\end{array}$ \\
\hline
\end{tabular}

*AI values in this column are significantly different from zero $(P<0 \cdot 001)$.

AChR patches. The AI for $43 \mathrm{~K}$ protein was approximately $0 \cdot 25$, and significantly different from zero under all treatment conditions (Table 3 ). The higher field strength and shorter PFR of the field treatment applied to the 1-or 2-day-old cells did not elevate the AI of the $43 \mathrm{~K}$ protein.

Table 3. $43 K$ protein elevation at field-induced $A C h R$ clusters

A. Computer-based quantitation

\begin{tabular}{|c|c|c|c|c|}
\hline Treatment & $\begin{array}{c}\text { Age } \\
\text { (days) }\end{array}$ & $\begin{array}{l}\text { AChR AI* } \\
\text { 土s.E.M. }\end{array}$ & $\begin{array}{l}43 \mathrm{~K} \mathrm{AI} \\
\pm \text { S.E.M. }\end{array}$ & No. expts, no. cells \\
\hline $\begin{array}{l}1-\mathrm{h} 4 \mathrm{~V} \mathrm{~cm}^{-1}, 2-\mathrm{h} \text { PFR } \\
3-\mathrm{h} 7.5 \mathrm{~V} \mathrm{~cm}^{-1}, \text { no PFR }\end{array}$ & $\begin{array}{l}1 \\
1\end{array}$ & $\begin{array}{l}0.460 \pm 0.027 \\
0.498 \pm 0.022\end{array}$ & $\begin{array}{l}0.270 \pm 0.030 \\
0.248 \pm 0.025\end{array}$ & $\begin{array}{l}2,16 \\
2,19\end{array}$ \\
\hline $\begin{array}{l}1-\mathrm{h} 4 \mathrm{~V} \mathrm{~cm} \mathrm{~cm}^{-1}, 2-\mathrm{h} \text { PFR } \\
3-\mathrm{h} 7.5 \mathrm{~V} \mathrm{~cm}^{-1}, 0 \cdot 2-\mathrm{h} \text { PFR }\end{array}$ & $\begin{array}{l}1 \\
2\end{array}$ & $\begin{array}{l}0.510 \pm 0.018 \\
0.429 \pm 0.026\end{array}$ & $\begin{array}{l}0.289 \pm 0.025 \\
0.199 \pm 0.025\end{array}$ & $\begin{array}{l}3,26 \\
2,15\end{array}$ \\
\hline
\end{tabular}

B. Experimenter-based quantitation

\begin{tabular}{|c|c|c|c|c|}
\hline Treatment & $\begin{array}{c}\text { Age } \\
\text { (days) }\end{array}$ & $\begin{array}{l}\text { \%o cells with } \\
\text { FIRPs }\end{array}$ & $\begin{array}{l}\text { \% FIRPs with } \\
43 \mathrm{~K}\end{array}$ & No. expts, no. cells \\
\hline $\begin{array}{l}\text { 1-h } 4 \mathrm{~V} \mathrm{~cm}^{-1}, 2 \text {-h PFR } \\
3-\mathrm{h} 7.5 \mathrm{~V} \mathrm{~cm}^{-1} \text {, no PFR }\end{array}$ & $\begin{array}{l}1 \\
1\end{array}$ & $\begin{array}{l}97 \\
96\end{array}$ & $\begin{array}{l}100 \\
100\end{array}$ & $\begin{array}{l}2,35 \\
2,31\end{array}$ \\
\hline $\begin{array}{l}1-\mathrm{h} 4 \mathrm{~V} \mathrm{~cm}-1,2-\mathrm{h} \text { PFR } \\
3-\mathrm{h} 7.5 \mathrm{~V} \mathrm{~cm}^{-1}, 0 \cdot 2-\mathrm{h} \text { PFR }\end{array}$ & $\begin{array}{l}1 \\
2\end{array}$ & $\begin{array}{r}98 \\
100\end{array}$ & $\begin{array}{l}100 \\
100\end{array}$ & $\begin{array}{l}3,57 \\
2,27\end{array}$ \\
\hline
\end{tabular}

*AI values in this column are significantly different from zero $(P<0 \cdot 001)$. 

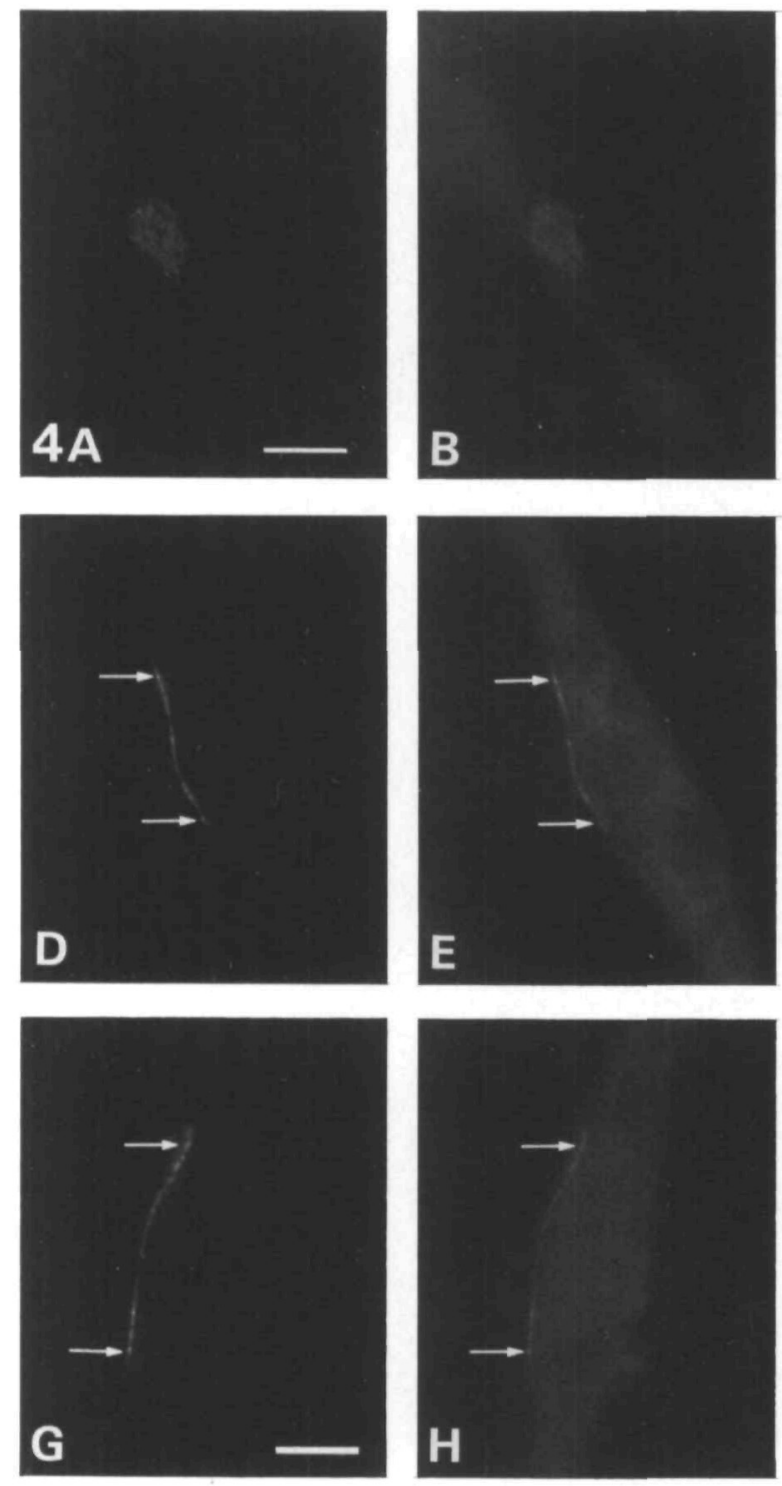
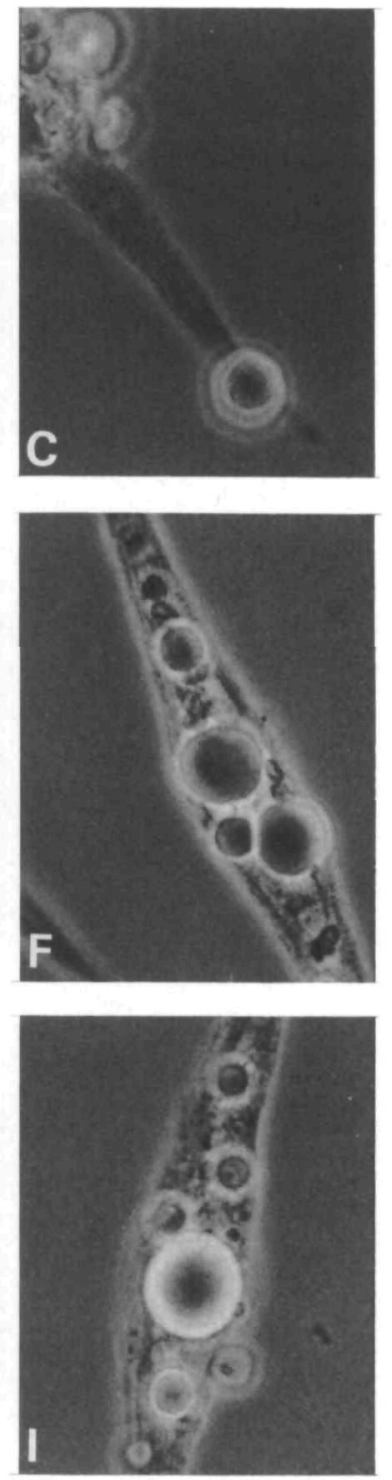

Fig. 4. 43K protein at hotspots and FIRPs. A,D,G, R-BTX staining; $\mathrm{B}, \mathrm{E}, \mathrm{H}$, the corresponding $43 \mathrm{~K}$ staining; $\mathrm{C}, \mathrm{F}, \mathrm{I}$, the corresponding phase-contrast views. The top row shows a muscle cell from an untreated culture. The staining pattern at the ventral hotspot $(\mathrm{A})$ matches the pattern of $43 \mathrm{~K}$ staining $(\mathrm{B})$ identically. Following the 1-h field, 2-h PFR (row 2) or the 3-h field, no PFR on 1-day-old cells (row 3), 43K (E,H arrows) was elevated at all FIRPs (D, G arrows). Cathode is to the left in this and all subsequent micrographs. Bar, $10 \mu \mathrm{m}$.
Talin in untreated and field-treated muscle cells In these cultures, talin was concentrated at many hotspots, although the distribution of the AChR (Fig. 5A) and talin (Fig. 5B) staining was usually different (arrows in Fig. 5A,B). In addition, talin was always elevated at the ends of cells (Fig. 5B, open arrow), where myofibrils are inserted into the plasma membrane. We found that talin was elevated at most, but not all, FIRPs. An example of talin elevation at a FIRP in a 1-day-old cell treated with the $4 \mathrm{~V} \mathrm{~cm}^{-1}$ protocol is shown in Fig. 5D-F (delimited by arrows). Talin was also elevated at most FIRPs in 1- and 2-day-old cultures treated with the $7.5 \mathrm{~V} \mathrm{~cm}^{-1}$ protocol (Fig. 5G-I, arrows). Talin remained elevated at the ends of the cells (not shown), and at most hotspots that remained after field treatment (not shown). For both protocols, the talin distribution more closely matches the distribution of FIRP staining than in the case of most hotspots (compare colocalization in Fig. 5A-C with that in Fig. 5D-I). We note, however, that since FIRPs are on the edge of the cell, colocalization cannot be assessed as well as at patches that form on horizontal regions of the cell membrane.

Talin was elevated at approximately $80 \%$ of the FIRPs on 1-day-old cells, and $87 \%$ of the FIRPs on 2-day-old cells (Table 4). Despite the variability in the association of talin with FIRPs, the AI for talin (and AChR) was significantly different from zero for all experimental protocols. The AI for talin in $7.5 \mathrm{~V} \mathrm{~cm}^{-1}$ treated 1 -dayold cells was not significantly greater than that of the $4 \mathrm{~V} \mathrm{~cm}^{-1}$ treated cells $(P>0 \cdot 05, t$-test). Also, the AI for the 2-day-old cells treated with $7.5 \mathrm{~V} \mathrm{~cm}^{-1}$ was not greater than that for the matched 1-day-old cells treated with $4 \mathrm{~V} \mathrm{~cm}^{-1}$.

\section{$58 K$ protein in untreated and field-treated muscle cells}

Like talin, $58 \mathrm{~K}$ protein is elevated at the ends of muscle cells in culture (not shown), regardless of whether AChR clusters are present. Unlike talin, however, the pattern of $58 \mathrm{~K}$ protein staining (Fig. $6 \mathrm{~B}$ ) is very similar to that of AChRs in hotspots (Fig. 6A). Following $4 \mathrm{~V} \mathrm{~cm}^{-1}$ field 

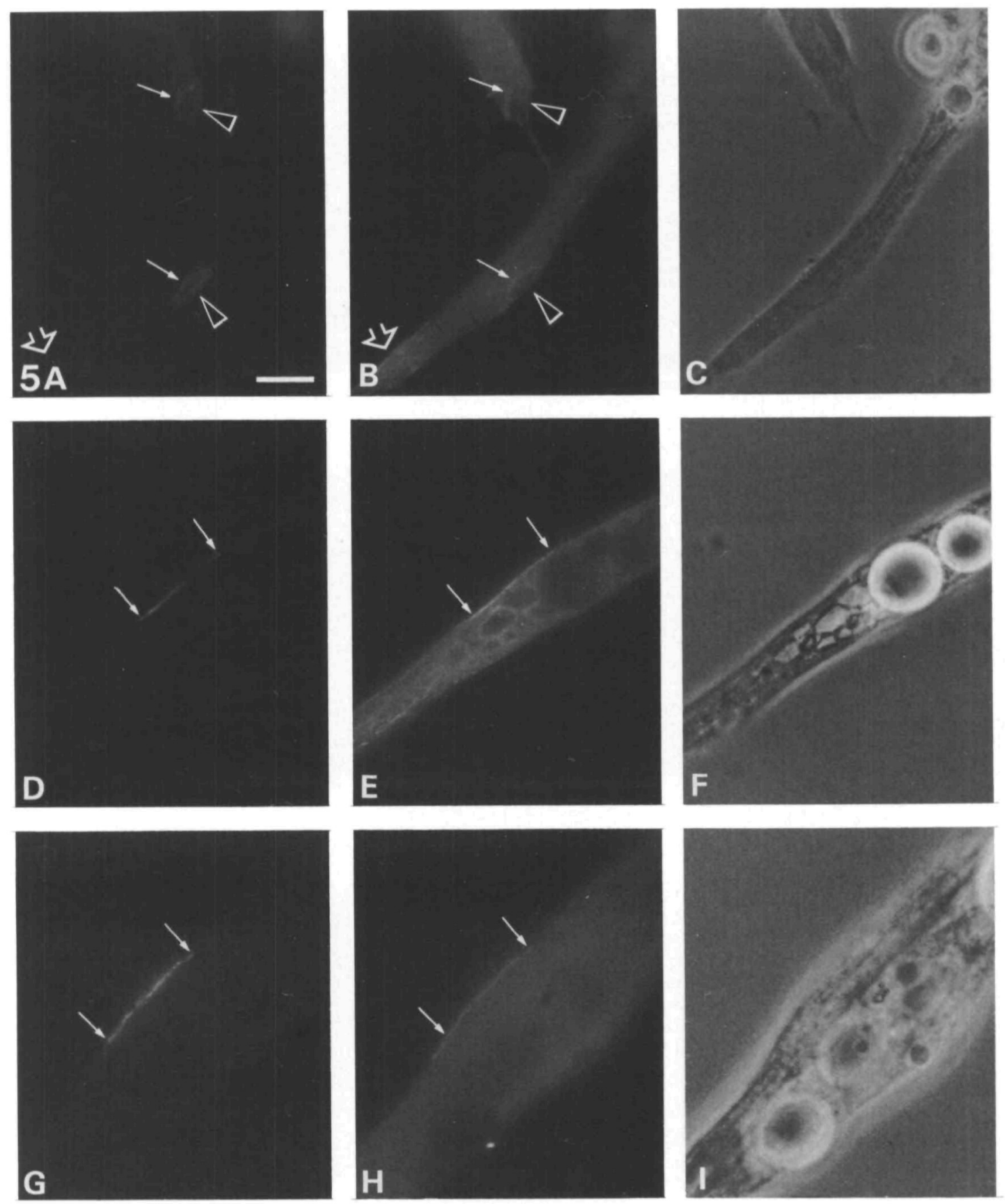

Fig. 5. Talin at hotspots and FIRPs, A,D,G, R-BTX staining; $B, E, H$, the corresponding talin staining; $C, F, I$, the corresponding phase-contrast views. The top row shows an example of a typical AChR (A) and talin (B) distribution in a 2-dayold untreated culture. Talin is always elevated at the ends of the myotomal muscle cells in vitro, independent of hotspot presence (A,B open arrows). Although there is overlap between the AChR and talin staining patterns (small arrows), there are regions of AChR staining that do not manifest a similar accumulation of talin (A,B arrowheads). After the 1-h field, 2-h PFR protocol, talin (E, arrows) was elevated at this FIRP (D, arrows). A particularly robust elevation of talin (H, arrows) was evident at the FIRP (G, arrows) induced by the 3-h field, no PFR treatment in this 2-day-old cell. A-F, bar, 10 $\mu \mathrm{m}$; G-I, $\mathrm{bar}=6 \mu \mathrm{m}$.

treatment of a 1 -day-old culture, $58 \mathrm{~K}$ protein (Fig. $6 \mathrm{E}$, arrows) is elevated at FIRPs (Fig. 6D, arrows). The $58 \mathrm{~K}$ protein staining at the ends of the cells is not abolished by field treatment, including that at the anodal edge of the end of the cell (not shown). Similarly, 58K protein
(Fig. 6H, arrows) is elevated at FIRPs (Fig. 6G, arrows) on $7.5 \mathrm{~V} \mathrm{~cm}^{-1}$ field-treated cells.

Virtually all of the FIRPs on either 1- or 2-day-old cells were also sites of $58 \mathrm{~K}$ protein accumulation (Table 5). The AI values for $58 \mathrm{~K}$ protein ranged from approxi- 
Table 4. Talin elevation at field-induced AChR clusters

A. Computer-based quantitation

\begin{tabular}{|c|c|c|c|c|}
\hline Treatment & $\begin{array}{l}\text { Age } \\
\text { (days) }\end{array}$ & $\begin{array}{l}\text { AChR AI* } \\
\text { 土S.E.M. }\end{array}$ & $\begin{array}{l}\text { Talin AI* } \\
\text { 土s.E.M. }\end{array}$ & No. expts, no. cells \\
\hline $\begin{array}{l}\text { 1-h } 4 \mathrm{~V} \mathrm{~cm}^{-1}, 2 \text {-h PFR } \\
3-\mathrm{h} 7.5 \mathrm{~V} \mathrm{~cm}^{-1}, \text { no PFR }\end{array}$ & $\begin{array}{l}1 \\
1\end{array}$ & $\begin{array}{l}0.498 \pm 0.014 \\
0.504 \pm 0.014\end{array}$ & $\begin{array}{l}0.070 \pm 0.015 \\
0.102 \pm 0.014\end{array}$ & $\begin{array}{l}2,31 \\
2,29\end{array}$ \\
\hline $\begin{array}{l}\text { 1-h } 4 \mathrm{~V} \mathrm{~cm}^{-1}, 2 \text {-h PFR } \\
\text { 3-h } 7.5 \mathrm{~V} \mathrm{~cm}^{-1}, 0 \cdot 2 \text {-h PFR }\end{array}$ & $\begin{array}{l}1 \\
2\end{array}$ & $\begin{array}{l}0.394 \pm 0.014 \\
0.358 \pm 0.015\end{array}$ & $\begin{array}{l}0.124 \pm 0.014 \\
0.070 \pm 0.019\end{array}$ & $\begin{array}{l}3,37 \\
2,32\end{array}$ \\
\hline \multicolumn{5}{|c|}{ B. Experimenter-based quantitation } \\
\hline Treatment & $\begin{array}{c}\text { Age } \\
\text { (days) }\end{array}$ & $\begin{array}{l}\text { \% cells with } \\
\text { FIRPs }\end{array}$ & $\begin{array}{l}\text { \%o FIRPs with } \\
\text { Talin }\end{array}$ & No. expts, no. cells \\
\hline $\begin{array}{l}\text { 1-h } 4 \mathrm{~V} \mathrm{~cm}^{-1}, 2 \text {-h PFR } \\
3-\mathrm{h} 7.5 \mathrm{~V} \mathrm{~cm}^{-1} \text {, no PFR }\end{array}$ & $\begin{array}{l}1 \\
1\end{array}$ & $\begin{array}{l}98 \\
95\end{array}$ & $\begin{array}{l}84 \\
84\end{array}$ & $\begin{array}{l}2,40 \\
2,40\end{array}$ \\
\hline $\begin{array}{l}\text { 1-h } 4 \mathrm{~V} \mathrm{~cm}^{-1}, 2-\mathrm{h} \text { PFR } \\
\text { 3-h } 7.5 \mathrm{~V} \mathrm{~cm}^{-1}, 0 \cdot 2-\mathrm{h} \text { PFR }\end{array}$ & $\begin{array}{l}1 \\
2\end{array}$ & $\begin{array}{r}92 \\
100\end{array}$ & $\begin{array}{l}75 \\
87\end{array}$ & $\begin{array}{l}9,242 \\
2,52\end{array}$ \\
\hline
\end{tabular}
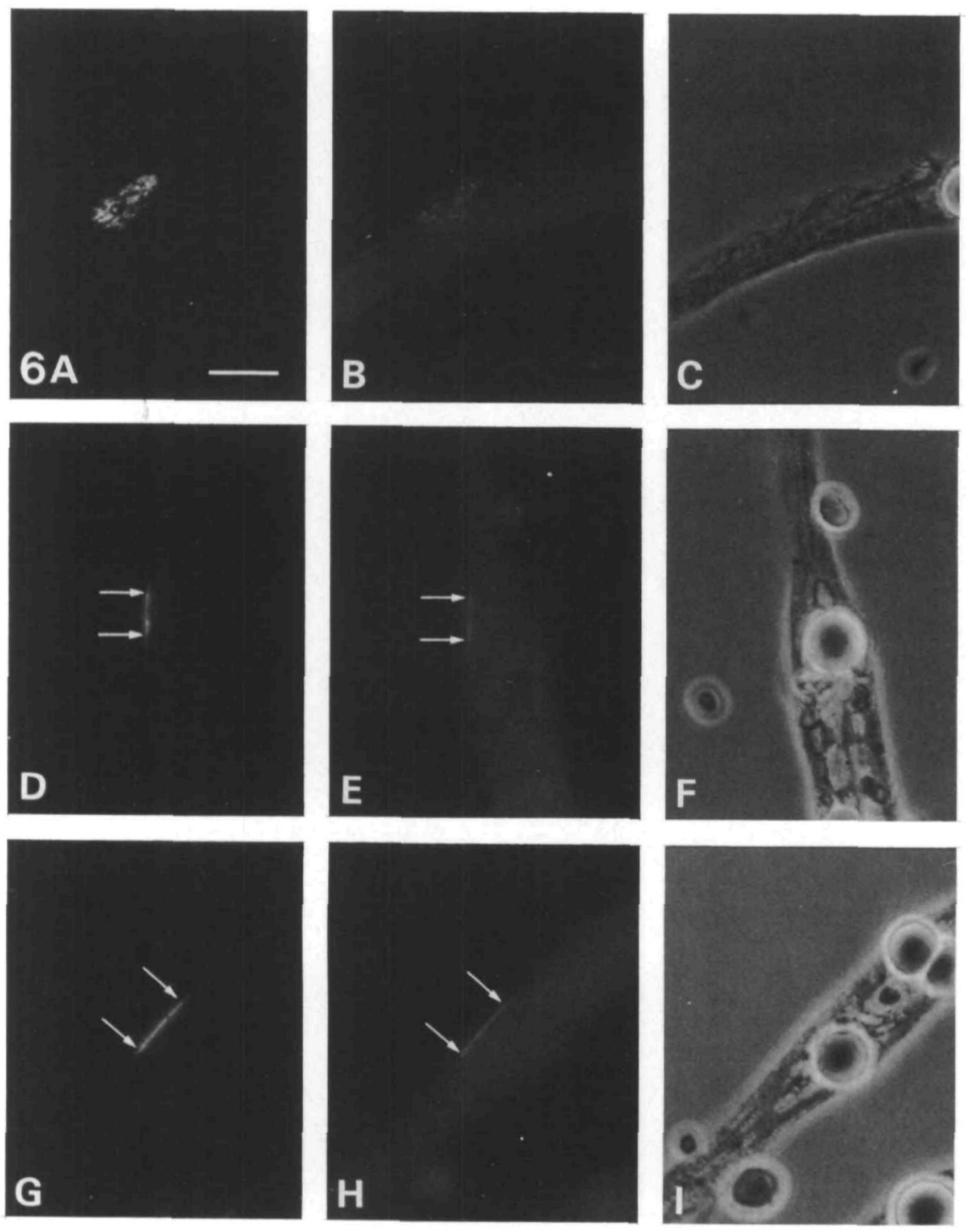

Fig. 6. $58 \mathrm{~K}$ protein at hotspots and FIRPs, A,D,G, R-BTX staining; $\mathrm{B}, \mathrm{E}, \mathrm{H}$, the corresponding $58 \mathrm{~K}$ staining; C,F, I, the corresponding phase-contrast views. The top row shows the colocalization between $58 \mathrm{~K}$ (B) and a ventral hotspot (A) in an untreated 1-day-old cell (C). Unlike talin, $58 \mathrm{~K}$ was typically well colocalized with AChR domains in hotspots. $58 \mathrm{~K}$ proteins (E,H arrows) was elevated at virtually all FIRPs (D, G arrows) induced by both the $1 \mathrm{~h}$ field, 2-h PFR protocol (row 2) and the 3-h field, no PFR protocol in 1-day-old cells (row 3). Bar, $10 \mu \mathrm{m}$. 
Table 5. $58 K$ protein elevation at field-induced AChR clusters

\section{A. Computer-based quantitation}

\begin{tabular}{|c|c|c|c|c|}
\hline Treatment & $\begin{array}{c}\text { Age } \\
\text { (days) }\end{array}$ & $\begin{array}{l}\text { AChR AI* } \\
\text { 土s.E.M. }\end{array}$ & $\begin{array}{l}58 \mathrm{~K} \mathrm{AI*} \\
\pm \text { s.Е.M. }\end{array}$ & No. expts, no. cells \\
\hline $\begin{array}{l}\text { 1-h } 4 \mathrm{~V} \mathrm{~cm}^{-1}, 2-\mathrm{h} \text { PFR } \\
3-\mathrm{h} 7.5 \mathrm{~V} \mathrm{~cm}^{-1} \text {, no PFR }\end{array}$ & $\begin{array}{l}1 \\
1\end{array}$ & $\begin{array}{l}0.574 \pm 0.015 \\
0.628 \pm 0.015\end{array}$ & $\begin{array}{l}0.163 \pm 0.014 \\
0.225 \pm 0.017\end{array}$ & $\begin{array}{l}2,25 \\
2,30\end{array}$ \\
\hline $\begin{array}{l}\text { 1-h } 4 \mathrm{~V} \mathrm{~cm}^{-1}, 2-\mathrm{h} \text { PFR } \\
3-\mathrm{h} 7.5 \mathrm{~V} \mathrm{~cm}^{-1}, 0 \cdot 2-\mathrm{h} \text { PFR }\end{array}$ & $\begin{array}{l}1 \\
2\end{array}$ & $\begin{array}{l}0.420 \pm 0.023 \\
0.582 \pm 0.029\end{array}$ & $\begin{array}{l}0.137 \pm 0.018 \\
0 \cdot 156 \pm 0.020\end{array}$ & $\begin{array}{l}3,26 \\
3,21\end{array}$ \\
\hline
\end{tabular}

B. Experimenter-based quantitation

\begin{tabular}{|c|c|c|c|c|}
\hline Treatment & $\begin{array}{c}\text { Age } \\
\text { (days) }\end{array}$ & $\begin{array}{l}\% \text { cells with } \\
\text { FIRPs }\end{array}$ & $\begin{array}{l}\text { \% FIRPs with } \\
58 \mathrm{~K}\end{array}$ & No. expts, no. cells \\
\hline 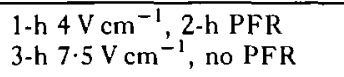 & $\begin{array}{l}1 \\
1\end{array}$ & $\begin{array}{r}95 \\
100\end{array}$ & $\begin{array}{l}100 \\
100\end{array}$ & $\begin{array}{l}2,40 \\
2,40\end{array}$ \\
\hline $\begin{array}{l}1-\mathrm{h} 4 \mathrm{~V} \mathrm{~cm}^{-1}, 2-\mathrm{h} \text { PFR } \\
3-\mathrm{h} 7.5 \mathrm{~V} \mathrm{~cm}^{-1}, 0 \cdot 2-\mathrm{h} \text { PFR }\end{array}$ & $\begin{array}{l}1 \\
2\end{array}$ & $\begin{array}{l}100 \\
100\end{array}$ & $\begin{array}{l}92 \\
93\end{array}$ & $\begin{array}{l}7,183 \\
3,32\end{array}$ \\
\hline
\end{tabular}

AI values in this column are significantly different from zero $(P<0.001)$.

mately $0 \cdot 14$ to $0 \cdot 23$, greater than those of talin. The AI was significantly greater for 1-day-old cells treated with the $7.5 \mathrm{~V} \mathrm{~cm}^{-1}$ protocol than for 1 -day-old cells treated with the $4 \mathrm{~V} \mathrm{~cm}^{-1}$ protocol. No significant difference was found between the AI of 2-day-old cells treated with $7 \cdot 5 \mathrm{~V} \mathrm{~cm}^{-1}$ and the AI of 1-day-old cells treated with $4 \mathrm{~V} \mathrm{~cm}^{-1}$, for $58 \mathrm{~K}$ protein.

\section{Discussion}

Previous work has shown that AChR patches induced by nerve, polycation-coated beads and applied electric fields have similar ultrastructures. Two salient features distinguish these AChR patches from non-patch regions: an accumulation of extracellular matrix material overlying the receptor-rich zone, and a sarcolemmal density marking this zone. However, whether antigens that are concentrated at postsynaptic specializations induced by nerve and bead are present at FIRPs has not been examined. Our earlier findings demonstrated that the colocalization of some antigens with AChR patches depended in part on the stimulus used to induce the receptor patch. For example, talin was always present at bead-associated receptor patches and substratum-associated hotspots, but was not detectable at $40 \%$ of the nerve-associated receptor patches or dorsal hotspots in vitro (Rochlin et al. 1989a). Since the electric field induces an AChR patch without physically contacting the cell, proteins such as talin, which are thought to accumulate in response to cell-substratum contact (Burridge $e t$ al. 1988), would not necessarily be expected to accumulate at FIRPs. Therefore, we investigated the role of three cytoplasmic proteins that are associated in different ways with postsynaptic specializations in Xenopus muscle cells in vitro.

All three antigens, $43 \mathrm{~K}, 58 \mathrm{~K}$ and talin, were concentrated at FIRPs. This elevation was evidenced by both experimenter- and computer-based methods of assessment. Moreover, the accumulation of these antigens persisted following a brief $(1 \mathrm{~h})$ field treatment and a longer $(2 \mathrm{~h}) \mathrm{PFR}$, indicating that these proteins became stabilized at the field-induced specialization. This observation raises the possibility that these antigens participate in the anchor that stabilizes AChRs at FIRPs. Since the AChRs were not distributed uniformly along the entire length of the cathode-facing sides of the cells, but in patches, the colocalization of these antigens with FIRPs provides additional support for this possibility. We note that although $43 \mathrm{~K}$ and $58 \mathrm{~K}$ were clearly concentrated at virtually all FIRPs, talin was not observably concentrated at approximately $20 \%$ of the FIRPs. Likewise, the AI for talin was less than that for $43 \mathrm{~K}$ and $58 \mathrm{~K}$ protein. In part this may be due to the higher background that accompanied talin staining. Nonetheless, in light of talin's variable relationship with $\mathrm{AChR}$ patches induced by other stimuli (e.g. nerve, see Rochlin et al. 1989a), the importance of its accumulation in the formation of this specialization is unclear.

Neither $58 \mathrm{~K}$ nor talin was removed from the ends of the cells following either field treatment. Since $58 \mathrm{~K}$ and talin remained elevated at both cathode- and anode-facing edges of the ends of the cells, we suspect that this specialization is stable against lateral diffusion or electrical mobility in the plasma membrane. In many cases, hotspots and FIRPs were absent from these specializations, suggesting that the mechanism that stabilizes $58 \mathrm{~K}$ and talin at the ends of the cells does not necessarily provide AChR stabilization. Thus, proteins associated with FIRPs may be immobilized by different mechanisms at different specializations.

Nerve and electric field not only induce receptor clusters with similar ultrastructure and antigen colocalization, but the induction process is similar as well. For both stimuli, AChR patches are stable only if influx of extracellular calcium is permitted (Stollberg \& Fraser, 1988). Nerve (Moody-Corbett \& Cohen, 1982b; Kuromi \& Kidokoro, 1984) and polycation-coated beads (Peng, 1986) eliminate hotspots and block the formation of hotspots on muscle cells that they contact. Since we (cf. 
Orida \& Poo, 1981) have shown that the number of cells with hotspots is decreased following field treatments, it is likely that hotspots formation and maintenance are also reduced by the electric field.

There are two possible mechanisms of field-induced membrane protein asymmetry. The field may directly propel proteins through the plane of the membrane and/or the field may trigger the formation of an anchoring specialization that does not depend on electrophoresis of the asymmetrically distributed protein. Although there are ample data supporting the inference of field-propelled protein movement in the plane of the membrane (Young et al. 1984), there are several findings that argue for fieldtriggering anchor formation: (1) AChR clustering proceeds; i.e. the AI increases, during the PFR following a brief field treatment (Stollberg \& Fraser, 1988). (2) The AChR AI is not strongly influenced by field strength, duration of field application, and PFR under conditions used in our experiments, indicating that the field does not add to the asymmetry generated by the anchor. (3) In spherical cells, membrane regions adjacent to sites of AChR clusters have lower fluorescence than more anodal regions, as expected of a diffusion trap, not of an electric field-propelled protein translocation (Stollberg \& Fraser, 1988). (4) In non-spherical cells, the asymmetries are concentrated in discrete regions of the cathode-facing edge of the cell, not distributed uniformly along the cathodal edge as predicted by electropropulsion. Since this non-uniformity is evident as early as $25 \mathrm{~min}$ following onset of field application (Fig. 2C, arrowheads), it is likely that the cluster foci are designated, following a very brief latency from the onset of field application. (5) Following neuraminidase treatment, an electric field causes AChRs to accumulate on the anodal edge of the cell and to decrease in concentration on the cathodal half of the cell (Orida \& Poo, 1978). Nonetheless, stable AChR patches form on the cathodal edge of the cell and the anodal accumulation disperses rapidly during PFR (Stollberg \& Fraser, 1989). Evidently, even when AChRs are electrophoresed towards the anodal site of the cell, the cluster stabilizing specialization only forms on the cathodal edge of the cell. We infer that the field triggers the formation of an anchor and that receptors will cluster at this anchor regardless of their local concentration in the nearby plasma membrane.

The anchor formation will entail the accumulation of non-AChR proteins that are required for stabilizing the FIRP against back diffusion. Others have suggested that the anchor may be external, since trypsin treatment eliminates the asymmetry of AChRs on field-treated cells, and cytoskeleton-disrupting agents (cytochalasin $B$ and colchicine) do not decrease the asymmetry (Orida \& Poo, 1980; Stollberg \& Fraser, 1988). Our data argue for the formation of an intracellular specialization, but do not address the question of whether externally exposed molecules are involved. The $43 \mathrm{~K}$ and $58 \mathrm{~K}$ proteins are probably components of this specialization, and talin may also be stabilized at these sites. The recent report that $43 \mathrm{~K}$ protein is not present at nascent $\mathrm{AChR}$ clusters in Torpedo embryos cautions against inferring that this (or any other protein) is essential for AChR clustering under all circumstances (Kordeli et al. 1989). In addition, this finding emphasizes the necessity of monitoring the accumulation of putative anchoring proteins at the earliest stages of cluster formation. The electric field induces AChR clusters rapidly and will enable us to determine which non-AChR proteins are present at the earliest stages of FIRP formation.

This work was supported by NIH grant NS-23583 and the Muscular Dystrophy Association (to H.B.P.). We gratefully acknowledge the help of Bronwen K. Nishikawa and Fen Zhang is carrying out some of the preliminary experiments.

\section{References}

Anderson, M. J. \& Cohen, M. W. (1977). Nerve-induced and spontaneous redistnbution of acetylcholine receptors on cultured muscle cells. 7. Phystol. (Lond.) 268, 757-773.

Bloch, R. J. \& GEIGER, B. (1980). The localization of acetylcholine receptor clusters in areas of cell-substrate contact in cultures of rat myotubes. Cell 21, 23-35.

Bloch, R. J., Morrow, J. S., Lindstrom, J. M. \& Froehner, S C. (1989). Comicroaggregation of acetylcholıne receptors and receptor-associated proteıns: evidence for a complex containing the $43 \mathrm{k}$ protein and $\beta$-spectrin. F. Cell Biol. 107, 513a.

Bloch, R. J. \& Pumplin, D. W. (1988). Molecular events in synaptogenesis: nerve-muscle adhesion and postsynaptic differentiation. Am. J. Physiol. 254, C345-C364.

Burden, S. J., Depalma, R. L. \& GotTesman, G. S. (1983). Crosslinking of proteins in acetylcholine receptor-rich membranes: association between the $\beta$-subunit and the $43 \mathrm{kd}$ subsynaptic protein. Cell 35, 687-692.

BURridge, K. \& ConNell, L. (1983). A new protein of adhesion plaques and ruffling membranes. F. Cell Biol. 97, 359-367.

Burridge, K., Fath, K., Kelly, T., Nuckolls, G. \& Turner, C. (1988). Focal adhesions: transmembrane junctions between the extracellular matrix and the cytoskeleton. A. Rev. Cell Biol. 4, $487-525$

Chen, Q., Sealock, R. \& Peng, H. B. (1989). Localization of the postsynaptic $58 \mathrm{k}$ protein at the myotendinous junction in Xenopus muscle fibers. F. Cell Biol. 107, 512a.

Christian, C. N., Daniels, M. P., Sugryama, H., Vogel, Z., JaCQues, L. \& Nelson, P. G. (1978). A factor from neurons increases the number of acetylcholine receptor aggregates on cultured muscle cells. Proc. natn. Acad. Sci. U.S.A. 75, 4011-4015.

Froehner, S. C. (1984). Peripheral proteins of postsynaptic membranes from Torpedo electric organ identified with monoclonal antıbodies. F. Cell Biol. 99, 88-96.

Froehner, S. C., Murnane, A. A., Tobler, M., Peng, H. B. \& SEALOCK, R. (1987). A postsynaptic $58 \mathrm{~K}$ protein concentrated at acetylcholine receptor-rich sites in Tonpedo electroplaques and skeletal muscle. J. Cell Biol. 104, 1633-1646.

Godfrey, E. W., Nitkin, R. M. \& Wallace, B. G. (1984). Components of Torpedo electric organ and muscle that cause aggregation of acetylcholine receptors on cultured muscle cells. $\mathcal{Y}$. Cell Biol. 99, 615-627.

Kordeli, E., Cartaud, J., Nghiem, H. O., Devillers-Thiery, A. \& Changeux, J. P. (1989). Asynchronous assembly of the acetylcholine receptor and of the $43-\mathrm{kd} v 1$ protein in the postsynaptic membrane of developing Torpedo mammorata electrocyte. 7. Cell Biol. 108, 127-139.

KrikoRlaN, J. G. \& BLOCH, R. J. (1989). Sulfhydryl reagents alter the interaction of the $43 \mathrm{k}$ protein with clustered acetylcholine receptor8. I. Cell Biol. 107, 513a.

Kullberg, R. W., Lentz, T. L. \& Cohen, M. W. (1977). Development of the myotomal neuromuscular junction in Xenopus laevis: An electrophysiological and fine-structural study. Devl Biol. 60, 101-129.

Kuromi, H. \& KıDokoro, Y. (1984). Nerve disperses preexisting acetylcholine receptor clusters prior to induction of receptor accumulation in Xenopus muscle cultures. Devl Biol. 103, 53-61. 
Lo, M. M. S., Garland, P. B., Lamprecht, J. \& Barnard, E. A. (1980). Rotational mobility of the membrane-bound acetylcholine receptor of Torpedo electric organ measured by phosphorescence depolarisation. FEBS Lett. 111, 407-412.

Luther, P. W. \& Peng, H. B. (1985). Membrane-related specializations associated with acetylcholine receptor aggregates induced by electric fields. J. Cell Biol. 100, 235-244.

Luther, P. W., Peng, H. B. \& LiN, J. J.-C. (1983). Changes in cell shape and actin distribution induced by constant electric fields. Nature, Lond. 303, 61-64.

Moody-CorbetT, F. \& Cohen, M. W. (1982a). Increased adhesiveness at sites of high acetylcholine receptor density on embryonic amphibian muscle cells cultured without nerve. $\mathcal{J}$. Embryol. exp. Morph. 72, 53-69.

Moody-Corbett, F. \& COHEN, M. W. (1982b). Influence of nerve on the formation and survival of acetylcholine receptor and cholinesterase patches on embryonic Xenopus muscle cells in culture. 7. Neurosci. 2, 633-646.

Nieuwkoop, P. D. \& FABER, J. (1967). Nonnal Tables of Xenopus laevis (Daudin), 2nd edn. North-Holland, Amsterdam.

OrIDA, N. \& Poo, M.-M. (1978). Electrophoretic movement and localisation of acetylcholine receptors in the embryonic muscle cell membrane. Nature, Lond. 275, 31-35.

OridA, N. \& Poo, M.-M. (1980). On the developmental regulation of acetylcholine receptor mobility in the Xenopus embryonic muscle membrane. Expl Cell Res. 130, 281-290.

Orida, N. \& Poo, M.-M. (1981). Maintenance and dissolution of acetylcholine receptor clusters in the embryonic muscle cell membrane. Devl Brain Res. 1, 293-298.

PenG, H. B. (1986). Elimınation of preexistent acetylcholine receptor clusters induced by the formation of new clusters in the absence of nerve. F. Neurosci. 6, 581-589.

PenG, H. B. (1987). Development of the neuromuscular junction in tissue culture. Crit. Rev. Anat. Sci. 1, 91-131.

Peng, H. B., Bridgman, P. C., Nakajima, S., Greenberg, A. \& NAKAJima, Y. (1979). A fast development of presynaptic function and structure of the neuromuscular junction in Xenopus tissue culture. Brain Res. 167, 379-384.

Peng, H. B. \& Froehner, S. C. (1985). Association of the postsynaptic $43 \mathrm{~K}$ protein with newly formed acetylcholine receptor clusters in cultured muscle cells. F. Cell Biol. 100, 1698-1705.

Peng, H. B. \& Nakajima, Y. (1978). Membrane particle aggregates in innervated and noninnervated cultures of Xenopus embryonic muscle cells. Proc. natn. Acad. Sci. USA 75, 500-504.

Peng, H. B. \& Phelan, K. A. (1984), Early cytoplasmic specialization at the presumptive acetylcholine receptor cluster: a meshwork of thin filaments. J. Cell Biol. 99, 344-349.

Rochlin, M. W., Chen, Q., Tobler, M., Turner, C. E. Burridge, K. \& Peng, H. B. (1989a). The relationship between talin and acetylcholine receptor clusters in Xenopus muscle cells. $\mathcal{~}$. Cell Sci. 92, 461-472.

Rochlin, M. W., Nishikawa, B. K., Zhang, F. \& Peng, H. B. $(1989 b)$. Talın, 58k protein, and $43 \mathrm{k}$ protein at acetylcholine receptor clusters induced by an electric field in Xenopus muscle cells. 7. Cell Biol. 107, 513a.

Sealock, R., Paschal, B., Beckerle, M. \& Burridge, K. (1986). Talın is a post-synaptic component of the rat neuromuscular junction. Expl Cell Res. 163, 143-150.

Sobel, A., Weber, M. \& Changeux, J.-P. (1977). Large scale purification of the acetylcholine-receptor protein in its membranebound and detergent-extracted forms from Torpedo mannorata electric organ. Eur. J. Biochem. 80, 215-224.

StOllberG, J. \& Fraser, S. E. (1988). Acetylcholine receptors and concanavalin A-binding sites on cultured Xenopus muscle cells: electrophoresis, diffusion, and aggregation. Y. Cell Brol. 107, 1397-1408.

Stollberg, J. \& Fraser, S. E. (1989). Mechanisms of acetylcholine receptor clustering: testing the tenable hypotheses biophysically. $\mathcal{J}$ Cell Biol. 107, 688a.

Takahashi, T., Nakajima, Y., Hirosawa, K., Nakjima, S. \& ONODERA, K. (1987). Structure and physiology of developing neuromuscular synapses in culture. 7 . Neurosci. 7, 473-481.

Tidball, J. G., O'Halloran, T. \& Burridge, K. (1986). Talin at myotendinous junctions. J. Cell Biol. 103, 1465-1472.

Usdin, T. B. \& Fischbach, G. D. (1986). Purification and characterization of a polypeptide from chick brain that promotes the accumulation of acetylcholine receptors in chick myotubes. $\mathcal{F}$. Cell Biol. 103, 493-507.

Weldon, P. R., Moody-Corbett, F. \& Cohen, M. W. (1981). Ultrastructure of sites of cholinesterase activity on amphibian embryonic muscle cells cultured without nerve. Devl Biol. 84, 341-350.

Young, S. H., McCloskey, M. \& Poo, M. (1984). Migration of cell surface receptors induced by extracellular electric fields: theory and applications. In The Receptors, vol. 1 (ed. M. Conn), pp. 511-539. New York: Academic Press.

(Received 8 May 1989 - Accepted 12 June 1989) 
